\title{
ARTICLE
}

Cite this: DOI: $10.1039 / \times 0 \times x 00000 x$

\section{Conformational preferences of Ac-Gly-NHMe in solution}

Received 00th January 2012,

Accepted 00th January 2012

DOI: $10.1039 / \times 0 \times x 00000 x$

www.rsc.org/

\author{
R. A. Cormanich, ${ }^{a, b}$ R. Rittner, ${ }^{*, b}$ and M. Bühl ${ }^{*}, a$
}

The conformational behaviour of Ac-Gly-NHMe in nonpolar, polar and polar protic solutions was systematically studied in this work by theoretical calculations and experimental infrared and ${ }^{1} \mathrm{H}$ NMR spectroscopies. Ac-Gly-NHMe prefers a gauche conformer with a strong sevenmembered intramolecular hydrogen bond for the isolated compound and in nonpolar solvents, but such preference changes in polar and polar protic solvents. Elucidation of Ac-Gly-NHMe preferences was also supported by studying the conformers of its $\mathrm{CF}_{3}-\mathrm{C}(\mathrm{O})-\mathrm{Gly}-\mathrm{NHMe}$ and Ac-Gly-N(Me $)_{2}$ derivatives in solution.

\section{Introduction}

The conformational equilibrium of amino acids and small peptides is a topic of intense research in the literature, which is being studied both experimentally and theoretically ${ }^{1}$ in order to elucidate polypeptide and protein polymeric chain structure and folding pathways. ${ }^{2}$ In particular, glycine, the simplest amino acid, is by far the most studied compound. Conformational preferences of glycine are, however, far from being fully understood. ${ }^{3}$ Indeed, conformational preferences of not only glycine, but of all amino acids are indicated to be the result of a complex interplay between intramolecular hydrogen bond (IHB) formation ${ }^{4}$ and steric and hyperconjugative interactions for the conformations, well-known e.g. for the simplest hydrocarbons. 5

In an effort to understand amino acid conformational preferences and the forces that govern such preferences we have been undertaking systematic studies for different amino acid compounds and some of their ester derivatives. ${ }^{6}$ Contrary to the common interpretations from the literature, we have found that the interplay between steric and hyperconjugative interactions and not IHBs are the main forces ruling the conformational behaviour of this important class of natural compounds.

The rationalization of the forces that govern peptide-like compounds of the general formula Ac-R-NHMe $(\mathrm{R}=$ amino acid) is desirable to understand the natural macromolecules that contain such amino acid residues as building blocks. In the present paper we report experimental ${ }^{1} \mathrm{H}$ NMR and infrared (IR) conformational studies of the dipeptide model Ac-GlyNHMe (1) and its fluorinated $\mathrm{CF}_{3}-\mathrm{C}(\mathrm{O})-\mathrm{Gly}-\mathrm{NHMe}(2)$ and $\mathrm{N}$ methylated Ac-Gly-N(Me) 2 (3) derivatives (Scheme 1). The experiments in solution are supported by theoretical calculations, in the framework of quantum topological methods as the Quantum Theory of Atoms in Molecules (QTAIM), ${ }^{7}$ Electron localization Functions $(E L F)^{8}$ and the recently developed Non-Covalent Interactions (NCI) ${ }^{9}$ and Density Overlap Regions Indicator ${ }^{10}$ methods and the orbital based Natural Bond Orbital (NBO) method. ${ }^{11}$<smiles>CNC(=O)CNC(C)=O</smiles><smiles>CNC(=O)CNC(=O)C(F)(F)F</smiles><smiles>CC(=O)NCC(=O)N(C)C</smiles>

Scheme 1: Ac-Gly-NHMe (1), $\mathrm{CF}_{3}-\mathrm{C}(\mathrm{O})-\mathrm{Gly}-\mathrm{NHMe}(2)$ and Ac-Gly-N(Me $)_{2}(3)$ structure representations.

\section{Experimental section}

NMR spectra. Compounds $\mathbf{1}, \boldsymbol{2}$ and $\mathbf{3}$ were purchased from Ukrorgsyntez Ltd. (UORSY) and used without further purification. ${ }^{1} \mathrm{H}$ NMR experiments were recorded on a Bruker Avance-III spectrometer operating at $600.17 \mathrm{MHz}$ for ${ }^{1} \mathrm{H}$. Spectra were recorded in solutions of ca. $1 \mathrm{mg}$ in $0.7 \mathrm{~mL}$ of $\mathrm{CD}_{2} \mathrm{Cl}_{2}$, acetone- $\mathrm{d}_{6}$, acetonitrile- $\mathrm{d}_{3}$, DMSO- $\mathrm{d}_{6}, \mathrm{CD}_{3} \mathrm{OH}$ and $\mathrm{H}_{2} \mathrm{O}(18.2 \mathrm{M} \Omega . \mathrm{cm}$ from a Millipore system). An insertion tube with $\mathrm{D}_{2} \mathrm{O}$ in the $\mathrm{H}_{2} \mathrm{O}$ sample was used in order to maintain the field-frequency lock and avoid deuteration of the $\mathrm{N}-\mathrm{H}$ bonds. Commercial solvents were referenced to internal TMS. Typical conditions used were as follows: a probe temperature of $25^{\circ} \mathrm{C}$, from 4 to 256 transients (depending on solute solubility), a spectral width of $6.0 \mathrm{kHz}, 64 \mathrm{k}$ data points, an acquisition time of $5.5 \mathrm{~s}$ and zero-filled to $128 \mathrm{k}$ points. The WATERGATE (water suppression by gradient-tailored excitation) ${ }^{12}$ and solvent presaturation ${ }^{13}$ approaches were used in order to suppress the $\mathrm{H}(\mathrm{O})$ solvent signal in the $\mathrm{H}_{2} \mathrm{O}$ and $\mathrm{CD}_{3} \mathrm{OH}$ solvents. ${ }^{1} \mathrm{H}$ NMR spectra are provided in the ESI.

IR spectra. The IR spectra were recorded on a FTIR Shimadzu IRPrestige-21 spectrometer equipped with a CsI beamsplitter. Spectra of compounds 1-3 were obtained in $\mathrm{CH}_{2} \mathrm{Cl}_{2}$ and acetonitrile solvents by using a $0.5 \mathrm{~mm}$ width $\mathrm{NaCl}$ round cell window with a concentration of $0.02 \mathrm{M}$. The following IR spectrometer conditions were used: number of scans $=128$, resolution $=2 \mathrm{~cm}^{-1}$, spectral range $=650-4000 \mathrm{~cm}^{-1}$. The equipment was purged with continuous dry nitrogen gas. Spectra in $\mathrm{H}_{2} \mathrm{O}(18.2 \mathrm{M} \Omega . \mathrm{cm}$ from a Millipore system) and $\mathrm{D}_{2} \mathrm{O}$ (99.9\% from Sigma Aldrich) were obtained with a $\mathrm{ZnSe} 45^{\circ}$ incidence angle Pike Tech ATR-8000HA horizontal attenuated total reflectance (HATR) sampling accessory. Reflectance spectra were converted to absorption spectra by the Kramers-Kronig analysis method. Experimental and predicted IR spectra are provided 
in the ESI. The experimental spectrum regions corresponding to $\mathrm{N}-\mathrm{H}$ stretching bands in $\mathrm{CH}_{2} \mathrm{Cl}_{2}$ and $\mathrm{CH}_{3} \mathrm{CN}$ were deconvoluted by using the GRAMS curve fitting software. ${ }^{14}$

Theoretical calculations. Conformers of 1, 2 and 3 were initially searched by 3-dimensional potential energy surfaces (PES) constructed by scanning its $\psi[\mathrm{N}-\mathrm{C}-\mathrm{C}(\mathrm{O})-\mathrm{N}]$ and $\phi[\mathrm{C}(\mathrm{O})-\mathrm{N}-\mathrm{C}-$ $\mathrm{C}(\mathrm{O})$ ] dihedral angles (Figure 1 ) from $0^{\circ}$ to $360^{\circ}$ in steps of $10^{\circ}$ at the B3LYP/cc-pVDZ level (Figure S1 in the ESI), using the Gaussian 09 program. ${ }^{15}$ This procedure, however, gave rise to only 2 conformers, $\mathbf{a}$ and $\mathbf{b},{ }^{16}$ for $\mathbf{1}$ and $\mathbf{2}$ and only one a conformer for $\mathbf{3}$ (Figure 2).

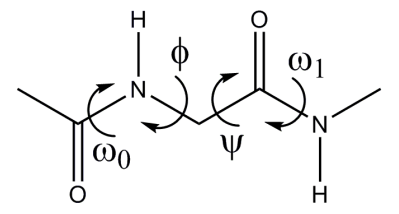

Figure 1: Dipeptide model dihedral angle representations.

Additionally, a B3LYP/cc-pVDZ Monte Carlo conformational search was carried out in Spartan 14 program $^{17}$ by using a $10 \mathrm{kcal}$ $\mathrm{mol}^{-1}$ threshold and $5000 \mathrm{~K}$ maximum temperature, which give rise to many more conformers, namely 11,9 and 7 for $\mathbf{1}, \mathbf{2}$ and $\mathbf{3}$, respectively (Figure S2 in the ESI). Optimisations and frequency calculations were carried out at the B3LYP and B3LYP-D3 levels for all conformers found in the Monte Carlo calculations, and the lack of negative frequencies confirmed that all conformers are energy minima. All conformers of compound 1 were re-optimised by using the B3LYP, BLYP, BP86, B97 and M06 functionals with and without DFT-D3 ${ }^{18,19}$ corrections and the MP2 ab initio method with the aug-cc-pVDZ basis set and also by using the AM1, PM3 and PM6 semi-empirical methods (energy values in Table $\mathrm{S} 1$ in the ESI) as implemented in the Gaussian 09 program. The B3LYP-D3/augcc-pVDZ level showed the smallest mean absolute deviation (MAD) from CCSD(T)-F12a/VDZ-F12 single point calculations performed on MOLPRO program ${ }^{20}$ (Table S1 in the ESI) and, hence, it was used in all subsequent calculations. The B3LYP-D3/aug-cc-pVDZ energies were converted into enthalpies and Gibbs free energies using standard thermodynamic corrections from the B3LYP-D3/augcc-pVDZ frequency calculations. The enthalpies were in better agreement with experimental IR populations than Gibbs free energies (see the section on infrared spectra in the ESI). All conformers were also optimised in the IEF-PCM [integral equation formalism variant of the Polarizable Continuum Model $]^{21}$ implicit solvent model at the B3LYP-D3/aug-cc-pVDZ level. NBO analysis ${ }^{11}$ was performed at the B3LYP-D3/aug-cc-pVDZ level employing geometries fully optimised at the same level for the isolated compounds. NMR ${ }^{3} J_{\mathrm{HH}}$ spin-spin coupling constant (SSCC) values were calculated at the BHandH/EPR-III level. ${ }^{22,23}$ This level was used because the $\mathrm{BHandH}$ functional performs well for a large variety of spin-spin coupling constants (SSCCs) involving carbon, fluorine and hydrogen atoms ${ }^{24}$ and the EPR-III basis set that was developed and optimised for the computation of the Fermi-contact term, which is usually the leading component of SSCCs. ${ }^{25}$ The second-order polarization propagator approximation (coupled cluster singles and doubles) SOPPA(CCSD) ${ }^{26}$ method was also used for comparison with the BHandH/EPR-III level. SOPPA(CCSD) calculations used the EPR-III basis set for ${ }^{1} \mathrm{H}$ and the cc-pVDZ basis for the remaining atoms and were ran in the Dalton 2013 program. $^{27}$ QTAIM, ELF, NCI and DORI topological analysis were carried out on the electron densities obtained from the B3LYP-D3/aug-ccpVDZ optimised geometries through the AIMALL 14.06.21, ${ }^{28}$ TopMod $^{29}$ and NCIPLOT 3.09 programs, respectively.

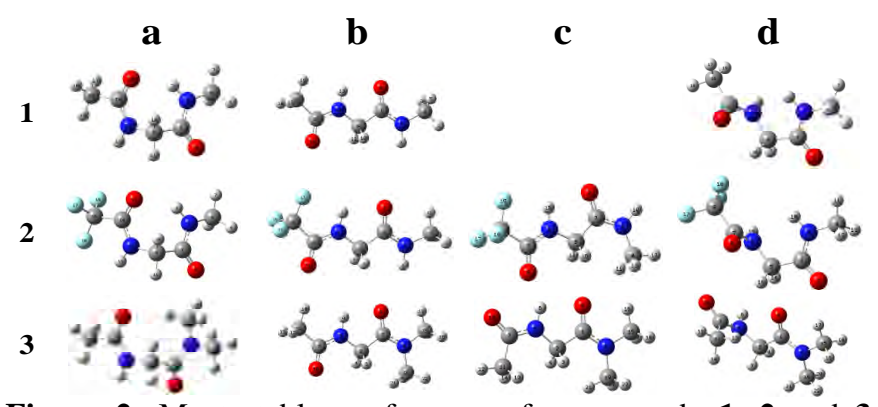

Figure 2: Most stable conformers of compounds 1, 2 and 3 optimised at the B3LYP-D3/aug-cc-pVDZ level (O red, $\mathrm{N}$ blue, C grey).

\section{Results and discussion}

Calculated conformer populations are shown in Table 1 for Ac-Gly-NHMe (1). These populations are derived from enthalpies obtained at the B3LYP-D3/aug-cc-pVDZ level for the isolated compound an in the IEF-PCM continuum media (geometrical representations of all conformers are given in Figure S2 in the ESI). Conformer 1 a is the global minimum for the isolated compound, corresponding to $61.1 \%$ of the total population. This conformer is also called as $\gamma^{16}$ in the literature, since it may be found in $\gamma$-turns of polypeptide and proteins; ${ }^{30}$ it has also been labeled $\mathbf{C 7}$, because it may form a $\mathrm{N}-\mathrm{H} \cdots \mathrm{O} 7$ membered IHB. ${ }^{31}$ With the IEF-PCM implicit model, the population of this conformer decreases to $46.1 \%$ in the fairly unpolar solvent $\mathrm{CH}_{2} \mathrm{Cl}_{2}$ and it is even smaller in more polar solvents (Table 1 ) with considerable increase of conformer $\mathbf{1 d}$, which may form a 5 -membered $\mathrm{N}-\mathrm{H} \cdots \mathrm{N}$ IHB (Table 1 and Figure 2). Population of conformer 1b, also called C5 in the literature (because it may form a 5 -membered $\mathrm{N}-\mathrm{H} \cdots \mathrm{O}$ IHB), ${ }^{16}$ decreases from the isolated compound to solution, but remains almost constant in the other solvents. The dipole moments $(\mu)$ of $1 \mathbf{a}, \mathbf{1 b}$ and $1 \mathbf{d}$ are calculated to be $3.27 \mathrm{D}, 3.35 \mathrm{D}$ and 5.22 $\mathrm{D}$, respectively. Thus, it is reasonable that population of conformer 1d increases with the dielectric constant of the media due to its higher dipole moment in comparison with 1a and $\mathbf{1 b}$.

Table 1: Conformer populations (in \%) of compound 1 from enthalpies $(\Delta H)$ obtained at the B3LYP-D3/aug-cc-pVDZ level for the isolated compound and in different IEF-PCM solvent models.

\begin{tabular}{cccccccc}
\multicolumn{2}{c}{ Isolated $\mathbf{C H}_{2} \mathbf{C l}_{2}$} & & acetone & $\mathbf{C H}_{3} \mathbf{C N}$ & DMSO & $\mathbf{C H}_{\mathbf{3}} \mathbf{O H}$ & $\mathbf{H}_{\mathbf{2}} \mathbf{O}$ \\
\hline $\mathbf{1 a}$ & 61.1 & 46.1 & 36.5 & 32.4 & 31.2 & 33.0 & 29.2 \\
$\mathbf{1 b}$ & 36.4 & 27.3 & 24.8 & 23.1 & 22.6 & 23.4 & 21.5 \\
$\mathbf{1 c}$ & 1.5 & 3.6 & 3.1 & 2.9 & 2.8 & 2.9 & 2.6 \\
$\mathbf{1 d}$ & 0.8 & 19.6 & 31.9 & 37.7 & 39.5 & 36.9 & 42.7 \\
$\mathbf{1 e}$ & 0.2 & 2.2 & 2.5 & 2.5 & 2.5 & 2.5 & 2.5 \\
$\mathbf{1 f}$ & 0.0 & 0.0 & 0.3 & 0.3 & 0.3 & 0.3 & 0.3 \\
$\mathbf{1 g}$ & 0.0 & 1.0 & 0.5 & 0.6 & 0.6 & 0.6 & 0.6 \\
$\mathbf{1 h}$ & 0.0 & 0.2 & 0.3 & 0.3 & 0.3 & 0.3 & 0.4 \\
$\mathbf{1 i}$ & 0.0 & 0.1 & 0.1 & 0.1 & 0.1 & 0.1 & 0.1 \\
$\mathbf{1 j}$ & 0.0 & 0.0 & 0.0 & 0.0 & 0.0 & 0.0 & 0.0 \\
$\mathbf{1 k}$ & 0.0 & 0.0 & 0.0 & 0.0 & 0.0 & 0.0 & 0.0 \\
\hline
\end{tabular}

Experimental and theoretical IR spectra of the amide $\mathrm{N}-\mathrm{H}$ bond stretching region of Ac-Gly-NHMe are shown in Figure 3 (in $\mathrm{CH}_{2} \mathrm{Cl}_{2}$ and $\mathrm{CH}_{3} \mathrm{CN}$ solvents). Only conformers $\mathbf{1 a}, \mathbf{1 b}$ and 1d, which account for $>90 \%$ of total population at the B3LYPD3/aug-cc-pVDZ level, were used for the theoretical. 
Experimental IR populations were corrected for each conformer with the calculated $\mathrm{N}-\mathrm{H}$ stretching intensities in $\mathrm{km} \mathrm{mol}^{-1}$ (for the graph of calculated intensity for each conformer see Figure $\mathrm{S} 3$ in the ESI). a)

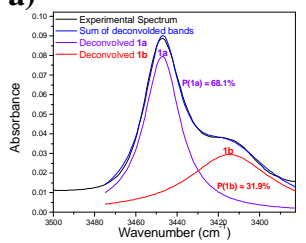

c)

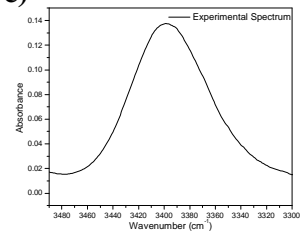

b)

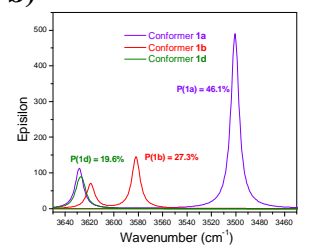

d)

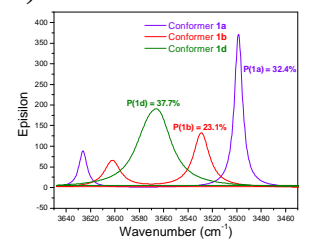

Figure 3: IR N-H bond stretching region for 1. a) Experimental deconvoluted spectrum in $\mathrm{CH}_{2} \mathrm{Cl}_{2}$. b) Theoretical B3LYPD3/aug-cc-pVDZ spectrum in $\mathrm{CH}_{2} \mathrm{Cl}_{2}$ (IEF-PCM). c) experimental spectrum in $\mathrm{CH}_{3} \mathrm{CN}$. d) Theoretical B3LYPD3/aug-cc-pVDZ spectrum in $\mathrm{CH}_{3} \mathrm{CN}$ (IEF-PCM). Conformer populations are indicated in each spectrum. Theoretical populations obtained at [B3LYP-D3/aug-cc-pVDZ] level. Experimental IR populations were corrected by calculated conformer molar absortivities.

The observed and calculated populations of $\mathbf{1 a}$ and $\mathbf{1 b}$ in $\mathrm{CH}_{2} \mathrm{Cl}_{2}$ are in reasonable agreement. ${ }^{32}$ From experimental IR, conformers 1a and $\mathbf{1 b}$ are the most populated conformers in $\mathrm{CH}_{2} \mathrm{Cl}_{2}$, with an observed population of $68.1 \%$ and $31.9 \%$, respectively (Figure 3 ). The calculated population of conformer 1a $(46.1 \%)$ is smaller than the observed experimental IR result and calculated population of conformer $\mathbf{1 b}(27.3 \%)$ is in good agreement with the experimental. Conformer 1d could not be observed experimentally, which IR band could be hidden below the most abundant $\mathbf{1 a}$ and $\mathbf{1 b}$ conformers. Population of conformer $1 \mathrm{~d}$ in $\mathrm{CH}_{2} \mathrm{Cl}_{2}$ is calculated to be of $19.6 \%$ at the B3LYP-D3/aug-cc-pVDZ level with IEF-PCM implicit solvent model. The IEF-PCM calculations in acetonitrile indicate that conformer 1d becomes the global minimum with $37.7 \%$ of the total population. However, the experimental N-H band of AcGly-NHMe in acetonitrile is much broader than in $\mathrm{CH}_{2} \mathrm{Cl}_{2}$ (Figure 3), presumably due to intermolecular $\mathrm{HB}$ formation with the solvent, and no experimental conformer population could be derived from this spectrum. It was also not possible to obtain the experimental populations in $\mathrm{H}_{2} \mathrm{O}$ and $\mathrm{D}_{2} \mathrm{O}$ from the amide $\mathrm{N}-\mathrm{H}$ stretching bands, since $\mathrm{H}_{2} \mathrm{O}$ absorbs strongly in the same region range as $\mathrm{N}-\mathrm{H}$ bands of $\mathbf{1}$ and also $\mathrm{D}_{2} \mathrm{O}$ absorbs in the same region as N-D bands, which arise from proton exchange with the solvent. However, experimental regions corresponding to amide $\mathrm{I}(\mathrm{C}=\mathrm{O}$ stretchings) and amide II bands [C(O)-N-H angular deformations] could be observed. While they present many shoulders in $\mathrm{CH}_{2} \mathrm{Cl}_{2}$ and $\mathrm{CH}_{3} \mathrm{CN}$, corresponding to a mix of conformers $\mathbf{1 a}, \mathbf{1 b}$ and $\mathbf{1 d}$ (Figure $4 \mathrm{a}, \mathrm{c})$, these bands seem to be more symmetrical in $\mathrm{H}_{2} \mathrm{O}$ and $\mathrm{D}_{2} \mathrm{O}$ (Figure 4e,f). Thus, one might infer that only one conformer would be present in water. However, the bands are very broad in water (presumably due to intermolecular HB formation between Ac-Gly-NHMe $\mathrm{C}=\mathrm{O}$ and $\mathrm{N}-\mathrm{H}$ bonds and the solvent); and bands from other conformers could just be hidden within. In fact, the IEF-PCM calculations (Table 1) indicate that all conformers $\mathbf{1 a}, \mathbf{1 b}$ and $\mathbf{1 d}$ would be present in considerable amount in water, $\mathbf{1 d}$ being the global minimum. a)

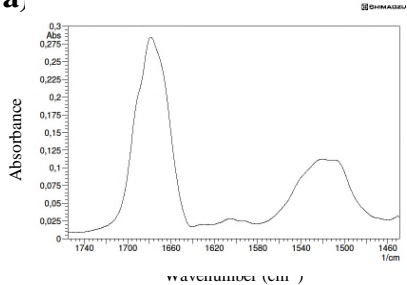

c)

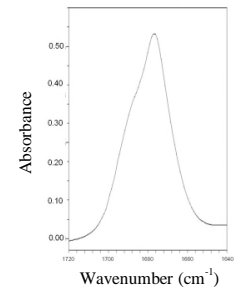

e)

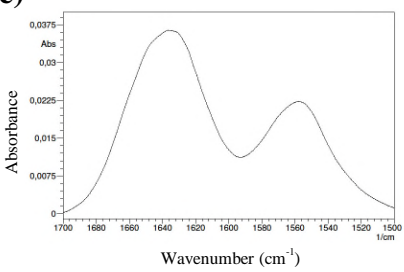

b)

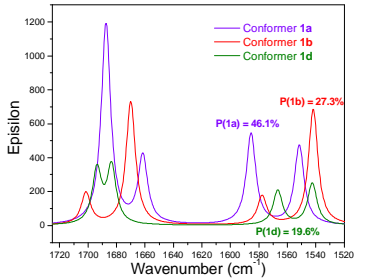

d)

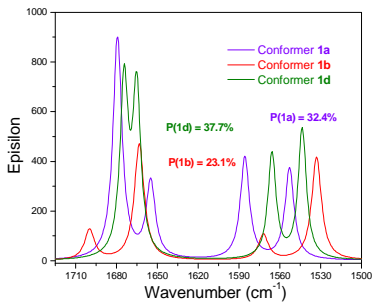

f

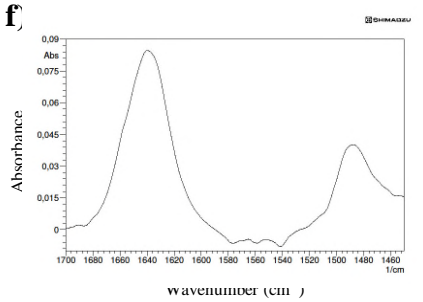

Figure 4: IR Amide I ( $\mathrm{C}=\mathrm{O}$ stretching) and II (N-H stretching) regions for 1. a) Experimental spectrum in $\mathrm{CH}_{2} \mathrm{Cl}_{2}$. b) Theoretical spectrum in $\mathrm{CH}_{2} \mathrm{Cl}_{2}$. c) Experimental spectrum in $\mathrm{CH}_{3} \mathrm{CN}$ (Amide I only, since $\mathrm{CH}_{3} \mathrm{CN}$ absorbs strongly in the Amide II region). d) Theoretical spectrum in $\mathrm{CH}_{3} \mathrm{CN}$. e) Experimental spectrum in $\mathrm{H}_{2} \mathrm{O}$. f) Experimental spectrum in $\mathrm{D}_{2} \mathrm{O}$. Theoretical spectra from conformers $\mathbf{1 a}, \mathbf{1 b}$ and $\mathbf{1 d}$ IR intensities/populations obtained at the B3LYP-D3/aug-ccpVDZ level with the IEF-PCM model.

QTAIM, ELF, NCI, DORI and NBO methods were then applied for the isolated Ac-Gly-NHMe conformers 1a, 1b and 1d in order to understand the intramolecular interactions that stabilise each conformer. The ELF, NCI, DORI and NBO methods found an IHB for all 3 conformers, while QTAIM found it only for conformer 1a (ESI Figure S4). Indeed, QTAIM is being repeatedly criticised in the literature, since it may not find a $\mathrm{HB}$ in situations where it is expected to be formed either by other theoretical methods or by experiment. ${ }^{33}$ The ELF, through the so-called core-valence bond index $(\mathrm{CVBI})^{34}$, indicates that conformer $\mathbf{1 a}$ forms the strongest IHB. The same is found with NCI and DORI, through the signal $\left(\lambda_{2}\right) \rho$ values from RDG and DORI peaks corresponding to IHB formation, and with $\mathrm{NBO}$ analysis, through $n \rightarrow \sigma^{*}{ }_{\mathrm{NH}}$ interaction energies (Table 2; details in the ESI Figures S4-S8). These findings are consistent with the short calculated $\mathrm{C}=\mathrm{O} \cdots \mathrm{H}-\mathrm{N}$ distance in the 7-membered ring closed by the IHB (2.04 ̊; Table 2). Larger distances are found in conformer $\mathbf{1 b}$, which forms a weak $\mathrm{C}=\mathrm{O} \cdots \mathrm{H}-\mathrm{N}$ IHB within a 5 membered ring $(2.21 \AA)$ and in $\mathbf{1 d}$, which forms the weakest $\mathrm{N} \cdots \mathrm{H}-\mathrm{N}$ hydrogen bond $(2.35 \AA)$. 
Table 2: IHB parameters for compounds 1 and $\mathbf{2}$ from QTAIM $(\rho)$, ELF $(\mathrm{CVBI}), \mathrm{NCI}$ and DORI $\left[\operatorname{sign}\left(\lambda_{2}\right) \rho\right.$ in au] and NBO orbital

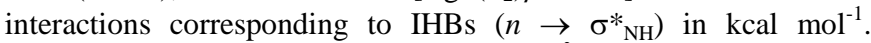
Calculated IHB distances are also shown in $\AA$.

\begin{tabular}{|c|c|c|c|c|c|c|c|}
\hline & \multicolumn{3}{|c|}{ Ac-Gly-NHMe } & \multicolumn{4}{|c|}{$\mathrm{CF}_{3}-\mathrm{C}(\mathrm{O})$-Gly-NHMe } \\
\hline & $1 \mathbf{a}$ & $1 \mathrm{~b}$ & 1d & $\mathbf{2 a}$ & $2 b$ & 2c & 2d \\
\hline$\rho$ & 0.022 & --- & --- & 0.017 & --- & --- & --- \\
\hline $\mathrm{CVBI}^{[\mathrm{a}]}$ & +0.012 & +0.032 & +0.042 & +0.027 & +0.030 & +0.030 & +0.045 \\
\hline $\operatorname{sign}\left(\lambda_{2}\right) \rho^{[b]}$ & -0.022 & -0.019 & -0.016 & -0.017 & -0.020 & -0.020 & -0.015 \\
\hline$n_{\mathrm{O}(\mathbf{1})} \rightarrow \sigma^{*}{ }_{\mathrm{NH}}$ & 2.57 & 0.67 & -- & 1.65 & 0.79 & 0.83 & --- \\
\hline$n_{\mathrm{O}(2)} \rightarrow \sigma^{*}{ }_{\mathrm{NH}}$ & 3.76 & 2.04 & --- & 2.69 & 2.49 & 2.59 & --- \\
\hline$n_{\mathrm{N}} \rightarrow \sigma_{\mathrm{NH}}^{*}$ & --- & --- & 1.24 & --- & --- & --- & 1.24 \\
\hline$n_{\mathrm{F}(2)} \rightarrow \sigma^{*}{ }_{\mathrm{NH}}$ & --- & --- & --- & 1.10 & 0.94 & 0.94 & 1.10 \\
\hline IHB distance & 2.04 & 2.21 & 2.35 & 2.14 & 2.19 & 2.18 & 2.37 \\
\hline
\end{tabular}

${ }_{\text {[a] }}$ More positive CVBI values correspond to weaker IHBs.

${ }^{[b]}$ More negative values correspond to stronger IHBs.

The N...H-N hydrogen bond in $\mathbf{1 d}$ may be rationalised to be weak due to the low availability of the amide nitrogen lone pairs $\left(n_{\mathrm{N}}\right)$, which are expected be in resonance within the $\mathrm{R}_{2} \mathrm{~N}$ $\mathrm{C}=\mathrm{O}$ amide fragment. Indeed, the Natural Resonance Theory (NRT), ${ }^{35}$ indicates that 3 from the 4 main Ac-Gly-NHMe resonance hybrids (from a total of 126) have the nitrogen lone pairs in resonance (Figure 5). All charged resonance hybrids strengthen the IHBs in conformers $\mathbf{1 a}$ and $\mathbf{1 b}$, but weaken the $\mathrm{N} \cdot \cdot \mathrm{H}-\mathrm{N}$ IHB in 1d IHB, since it localises negative charges in the $\mathrm{O}$ atoms ( $\mathrm{H}$ atom acceptors in $\mathbf{1 a}$ and $\mathbf{1 b})$ and positive charges on the $\mathrm{N}$ atoms ( $\mathrm{H}$ atom acceptor in $\mathbf{1 d}$ ).

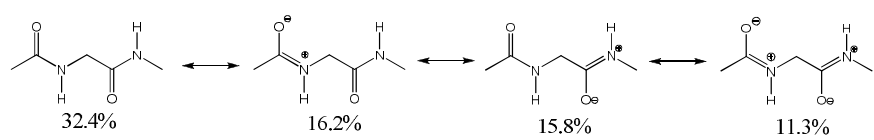

Figure 5: Main resonance contributor percentages obtained from the NRT analysis to Ac-Gly-NHMe conformer 1a. Percentage values for conformers $\mathbf{1 b}$ and $\mathbf{1 d}$ are almost the same, with a maximum deviation of only $1.6 \%$.

That is worth to mention that both NCI and DORI found other weak intramolecular interactions, as 5-membered $\mathrm{O} \cdots \mathrm{H}$ $\mathrm{C}$ not usual IHBs, that could not be found by QTAIM, ELF and NBO methods, wherein DORI found the highest number of those interactions (ESI; Figures S4-S8). Such interactions are indicated to be stabilising by both NCI and DORI. However, both NCI and DORI use the sign of $\lambda_{2}$ parameter in order to differentiate stabilising and destabilising interactions. As observed in previous works: "care is recommended when interpreting the sign of $\lambda_{2}$ in very weak interactions, because in these cases the sign might depend on the method of calculation". 36

Relative total enthalpy corrected energies $[\Delta H(\mathrm{~T})]$, Natural non-Lewis (hyperconjugative) contribution energies $[\Delta H(\mathrm{NL})]$ and Natural Lewis Structure (steric/electrostatic) contribution energies $[\Delta H(\mathrm{~L})]$ for conformers $\mathbf{1 a}, \mathbf{1 b}$ and $\mathbf{1 d}$ obtained from NBO analysis (deletion of all donor-acceptor interactions) at the B3LYP-D3/aug-cc-pVDZ level are collected in Table 3.

Table 3: Total relative enthalpies $[\Delta H(\mathrm{~T})]$, energy of the hypothetical case where hyperconjugation is removed $[\Delta H(\mathrm{~L})],{ }^{[\mathrm{a}]}$ and hyperconjugative energy $[\Delta H(\mathrm{NL})],{ }^{[\mathrm{a}]}$ all in kcal $\mathrm{mol}^{-1}$, for Ac-Gly-NHMe conformers 1a, $\mathbf{1 b}$ and $\mathbf{1 d}$ isolated and in different media (IEF-PCM). Calculations at the B3LYPD3/aug-cc-pVDZ level.

\begin{tabular}{|c|c|c|c|c|c|c|c|c|}
\hline & & Isolated & $\mathrm{CH}_{2} \mathrm{Cl}_{2}$ & Acetone & Acetonitrile & DMSO & $\mathrm{CH}_{3} \mathrm{OH}$ & $\mathrm{H}_{2} \mathrm{O}$ \\
\hline \multirow{3}{*}{$1 \mathbf{a}$} & $\Delta H(\mathrm{~T})$ & 0.00 & 0.00 & 0.00 & 0.09 & 0.14 & 0.07 & 0.23 \\
\hline & $\Delta H(\mathrm{~L})$ & 11.00 & 11.93 & 11.91 & 11.90 & 11.87 & 11.90 & 11.90 \\
\hline & $\Delta H(\mathrm{NL})$ & 13.57 & 12.44 & 11.99 & 11.81 & 11.73 & 11.83 & 11.67 \\
\hline \multirow{4}{*}{$1 b$} & $\Delta H(\mathrm{~T})$ & 0.31 & 0.31 & 0.23 & 0.29 & 0.33 & 0.27 & 0.41 \\
\hline & $\Delta H(\mathrm{~L})$ & 2.14 & 3.43 & 3.47 & 3.48 & 3.46 & 3.48 & 3.47 \\
\hline & $\Delta H(\mathrm{NL})$ & 4.40 & 3.63 & 3.32 & 3.19 & 3.13 & 3.21 & 3.06 \\
\hline & $\Delta H(\mathrm{~T})$ & 2.57 & 0.51 & 0.08 & 0.00 & 0.00 & 0.00 & 0.00 \\
\hline \multirow[t]{2}{*}{ 1d } & $\Delta H(\mathrm{~L})$ & 0.00 & 0.00 & 0.00 & 0.00 & 0.00 & 0.00 & 0.00 \\
\hline & $\Delta H(\mathrm{NL})$ & 0.00 & 0.00 & 0.00 & 0.00 & 0.00 & 0.00 & 0.00 \\
\hline
\end{tabular}

${ }^{\text {[a] }}$ Obtained by adding the enthalpic corrections from $\Delta H(\mathrm{~T})$.

Table 3 indicates that 1a suffers the highest steric interactions [ $\Delta H(\mathrm{~L})$ values], followed by $\mathbf{1 b}$ and $\mathbf{1 d}$ as the conformer that experiences the lowest steric interactions. Hyperconjugative stabilisation operates in the other way round $[\Delta H(\mathrm{NL})$ values], i.e., it is highest for $\mathbf{1 a}$ and lowest for 1d. Conformer $\mathbf{1 a}$ is the most stable for the isolated compound, and it has an approximately gauche geometry, with dihedral angles of $\phi[\mathrm{N}-\mathrm{C}-\mathrm{C}(\mathrm{O})-\mathrm{N}]=68.6^{\circ}$ and $\psi$ $[\mathrm{C}(\mathrm{O})-\mathrm{N}-\mathrm{C}-\mathrm{C}(\mathrm{O})]=81.2^{\circ}$. Thus, the conformational preference in Ac-Gly-NHMe is a consequence of the well known gauche effect, ${ }^{37}$ i.e., $\mathbf{1 a}$ is the lowest energy conformer even though it experiences the highest steric and electrostatic destabilisation. The stability of conformer 1a is assisted by its strong IHB within a 7-membered ring, which explains its high hyperconjugative stabilisation by increasing it by $6.33 \mathrm{kcal} \mathrm{mol}^{-1}\left(n_{\mathrm{O}(1)} \rightarrow \sigma^{*}{ }_{\mathrm{NH}}=2.57 \mathrm{kcal} \mathrm{mol}^{-1}+\right.$ $n_{\mathrm{O}(2)} \rightarrow \sigma^{*}{ }_{\mathrm{NH}}=3.76$; orbital representations in the ESI; Figure S8). The Natural Steric Analysis (NSA) ${ }^{38}$ is in qualitative agreement with the $\Delta H(\mathrm{~L})$ energy parameter and indicates that $\mathbf{1 a}$ is more destabilised due to steric interactions $\left(+250.27 \mathrm{kcal} \mathrm{mol}^{-1}\right)$ than $\mathbf{1 b}$ $\left(+249.66 \mathrm{kcal} \mathrm{mol}^{-1}\right)$ and 1d $\left(+245.67 \mathrm{kcal} \mathrm{mol}^{-1}\right)$, whose steric energy values are not due to any particular orbital-orbital interaction, but the contributions sum of all of them.

As shown previously, theory indicates that conformer 1d becomes the most stable in acetonitrile. Indeed, the stability of $\mathbf{1 a}$ is highly dependent on its $\mathrm{N}-\mathrm{H} \cdots \mathrm{O} 7$-membered IHB, while that of conformer 1d is due to its minor destabilisation by steric effects. Also, 1b could have increased population in polar solvents not only due to its higher dipole moment, but also due to its smaller dependence of IHB stabilisation than $\mathbf{1 a}$ and $\mathbf{1 b}$.

Table 4: Experimental chemical shifts (ppm) and ${ }^{3} J_{\mathrm{HH}}$ spin-spin coupling constants (SSCCs, Hz) of Ac-Gly-NHMe in solvents with different dielectric constants $(\varepsilon)$.

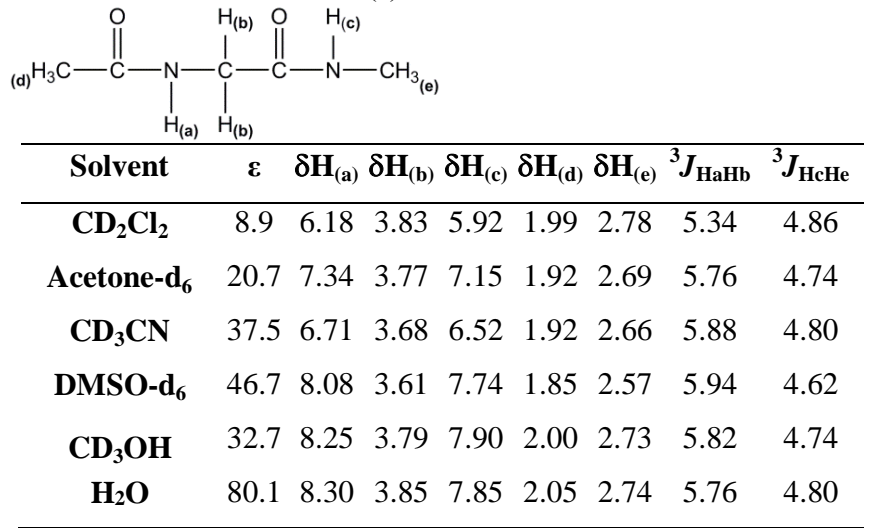


We turn now to ${ }^{1} \mathrm{H}$ NMR, experimental ${ }^{3} J_{\mathrm{HH}}$ spin-spin coupling constant (SSCC) and chemical shift values (Table 4). The ${ }^{3} J_{\mathrm{HaHb}}$ values are almost constant in the studied solvents. Based on the well known Karplus relationship, ${ }^{39}$ one would expect that the ${ }^{3} J_{\mathrm{HaHb}}$ values would be similar for $\mathbf{1 a}$ and $\mathbf{1 d}$, with higher values than $\mathbf{1 b}$, since the former conformers have a both cis and an anti relationship between $\mathbf{H a}$ and $\mathbf{H b}$ atoms, while $\mathbf{1 b}$ has only anticlinal relationships between these atoms (Figure 6). Thus, the observation that the ${ }^{3} J_{\mathrm{HaHb}}$ values are almost constant in different solvents would be either because the conformer populations do not change among the applied solvents or that the populations are shifting from conformer 1a to 1d, which have similar ${ }^{3} J_{\mathrm{HaHb}}$ values. IEF-PCM calculations (Table 1) suggest that the second hypothesis is the correct one, i.e., the population of $\mathbf{1 b}$ is almost constant in the different solvents and that of $\mathbf{1 a}$ shifts to $\mathbf{1 d}$ when the solvent polarity increases.

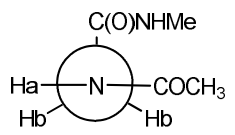

1a

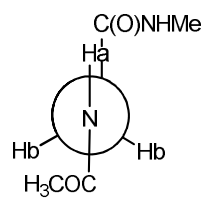

$1 \mathrm{~b}$

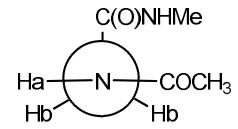

1d
Figure 6: Newman representations of conformers of $\mathbf{1}$.

BHandH/EPR-III and SOPPA(CCSD)/EPR-III ${ }^{3} J_{\mathrm{HaHb}}$ SSCCs for all 1 conformers are given in the ESI (Table S5). Both methods indicate that the ${ }^{3} J_{\mathrm{HaHb}}$ values for $\mathbf{1 a}$ and $\mathbf{1 d}$ are indeed similar $(\sim 7$ and $\sim 6 \mathrm{~Hz}$, respectively) and higher than the corresponding values for $\mathbf{1 b}[\sim 3 \mathrm{~Hz}$ for $\mathrm{BHandH}$ and $\sim 2 \mathrm{~Hz}$ for SOPPA(CCSD), respectively]. Figure 7 a shows the calculated ${ }^{3} J_{\mathrm{HaHb}}$, weighted by all populations of conformer 1 . In this case, BHandH/EPR-III results are in better agreement with experiment than SOPPA(CCSD)/EPRIII. Figure $7 \mathrm{~b}$ uses corrected IR populations (from Figure 3) and BHandH/EPR-III calculated ${ }^{3} J_{\mathrm{HaHb}}$ values. ${ }^{3} J_{\mathrm{HaHb}}$ values obtained from theoretical and IR-derived populations in $\mathrm{CH}_{2} \mathrm{Cl}_{2}$ are in reasonable accordance $(4.76 \mathrm{~Hz}$ and $5.77 \mathrm{~Hz})$ with the experimental value $(5.34 \mathrm{~Hz})$ and theoretical is in excellent agreement in $\mathrm{CH}_{3} \mathrm{CN}$ (theoretical $=5.87 \mathrm{~Hz}$; Experimental $=5.98 \mathrm{~Hz}$ ). Thus, theory and experimental IR and ${ }^{1} \mathrm{H}$ NMR indicates that $\mathbf{1 a}$ and $\mathbf{1 b}$ are preferred for the isolated compound and in nonpolar solvents, but $1 \mathbf{d}$ is the preferential one and compete with $\mathbf{1 b}$ in more polar solvents. If mostly one conformer is present in water, it may not be $\mathbf{1 b}$, even though it has an extended geometry and presumably smaller $\Delta G$ of solvation than the remaining conformers, because the calculated ${ }^{3} J_{\mathrm{HaHb}} \mathrm{SSCC}$ for $\mathbf{1 b}(\mathrm{BHandH}=2.7 \mathrm{~Hz}$ and SOPPA $=1.8 \mathrm{~Hz}$; ESI Table S5) is much smaller than the experimental $(5.6 \mathrm{~Hz})$. On the other hand, conformer 1d more closely matches the experimental value in water $(\mathrm{BHandH}=7.2 \mathrm{~Hz}$ and $\mathrm{SOPPA}=6.2 \mathrm{~Hz})$. The competition between $\mathbf{1 b}$ and $\mathbf{1 d}$ in water is in agreement with previous molecular dynamics and QM/MM studies from the literature, which found both $\mathbf{1 b}$ and $\mathbf{1 d}$ depending on the level of calculation $^{40}$ and that $\mathbf{1 d}$ should be the preferential if increased number of water molecules are taken into accout. Indeed, by simulating 11 water molecules around Ac-Gly-NHMe, Boopathi et $a{ }^{41}$ showed, by using molecular dynamics calculations, that conformer $1 \mathbf{d}$ would be the preferential one in water. a)

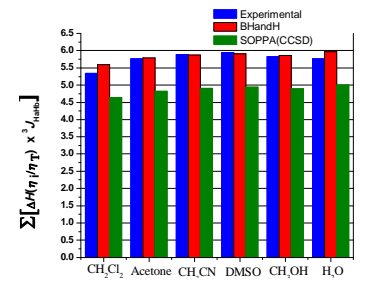

b)

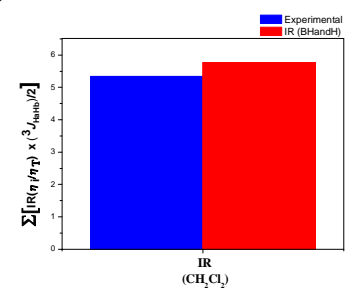

Figure 7: Sum of the weighted contributions $\left[\left(n_{\mathrm{i}} / n_{\mathrm{T}}\right) \times J\right.$ for the ${ }^{3} J_{\mathrm{HaHb}}$ couplings of all Ac-Gly-NHMe conformers (obtained as $\left.{ }^{3} J_{\mathrm{H} 10 \mathrm{H} 11}+{ }^{3} J_{\mathrm{H} 11 \mathrm{H} 13} / 2\right)$; SSCCs were obtained in different solvents (B3LYP-D3/aug-cc-pVDZ level optimisation) by using the IEF-PCM model. a) conformer contributions obtained from $\Delta H$ populations and b) conformer contributions obtained from experimental IR populations in $\mathrm{CH}_{2} \mathrm{Cl}_{2}$ (using BHandH/EPR-III calculated $\left.{ }^{3} J_{\mathrm{HH}}\right)$.

In order to get a deeper insight into the factors that govern conformer stability in the more polar solvents, we decided to "manipulate" the H-bond in both $\mathbf{1 a}$ and $1 \mathbf{d}$ by studying the $\mathrm{CF}_{3}-\mathrm{C}(\mathrm{O})-\mathrm{Gly}-\mathrm{NHMe}(2)$ derivative. The electron withdrawing $\mathrm{CF}_{3^{-}}$group should weaken the $\mathrm{C}=\mathrm{O} \cdots \mathrm{H}-\mathrm{N}$ IHB in $\mathbf{2 a}$ and $\mathbf{2 d}$ (representations in Figure 2) in comparison to $\mathbf{1 a}$ and $\mathbf{1 d}$, because it withdraws electron density from the $\mathrm{H}$ atom acceptor groups in these conformers. Also, the $\mathrm{CF}_{3^{-}}$group may strengthen the IHB in conformer $\mathbf{2 b}$ in comparison to $\mathbf{1 b}$, since it withdraws electron density from the $\mathrm{H}(\mathrm{N})$ atom participating in the IHB in this conformer. All ELF, NCI, DORI and NBO parameters indicate that this is indeed the case (Table 2). QTAIM again could find an IHB only for conformer 2a. All methods, except QTAIM, also indicate formation of a CF $\cdots \mathrm{HN}$ IHB for conformers $\mathbf{2 a - 2 d}$, which is of similar strength for all of them $\left(n_{\mathrm{F}(2)} \rightarrow \sigma^{*}{ }_{\mathrm{NH}}\right.$ interaction energies; Table 2$)$.

Table 5: Conformer populations (in \%) from enthalpies $(\Delta H)$ of compounds $\mathbf{2}$ and 3, obtained at the B3LYP-D3/aug-ccpVDZ level for the isolated compound and in different IEFPCM solvents.

\begin{tabular}{|c|c|c|c|c|c|c|c|}
\hline \multicolumn{7}{|c|}{ isolated $\mathrm{CH}_{2} \mathrm{Cl}_{2}$ acetone $\mathrm{CH}_{3} \mathrm{CN}$ DMSO $\mathrm{CH}_{3} \mathrm{OH}$} & \multirow{2}{*}{$\begin{array}{r}\mathrm{H}_{2} \mathbf{O} \\
6.0\end{array}$} \\
\hline $2 \mathbf{a}$ & 15.8 & 8.4 & 6.8 & 6.4 & 6.2 & 6.4 & \\
\hline $2 \mathbf{b}$ & 81.1 & 74.5 & 72.2 & 70.7 & 70.2 & 70.9 & 69.4 \\
\hline $2 \mathrm{c}$ & 3.03 & 9.3 & 8.3 & 8.0 & 7.9 & 8.0 & 7.8 \\
\hline $2 d^{[a]}$ & --- & 7.6 & 12.5 & 14.8 & 15.5 & 14.5 & 16.5 \\
\hline $3 \mathbf{a}$ & 2.1 & 2.6 & 3.0 & 3.1 & 3.2 & 3.1 & 3.3 \\
\hline $3 \mathbf{b}$ & 97.7 & 93.6 & 91.0 & 89.6 & 89.1 & 89.8 & 88.3 \\
\hline $3 c$ & 0.2 & 3.2 & 5.0 & 5.8 & 6.1 & 5.7 & 6.6 \\
\hline $3 d$ & 0.0 & 0.3 & 0.5 & 0.6 & 0.7 & 0.6 & 0.8 \\
\hline
\end{tabular}

[a] $\mathbf{2 d}$ is not a minimum for the isolated molecule.

Theory indicates that conformer $\mathbf{2 a}$ is not the most stable conformer. Conformer $\mathbf{2 b}$ is the most stable one with more than $80 \%$ of the total population of $\mathbf{2}$ (Table 5). Such relative stability decreases in more polar solvents and $\mathbf{2 d}$ becomes progressively more stable as the dielectric constant increases. IR populations are not in quantitative agreement with theory. Although $2 \mathbf{b}$ conformer is the most stable in $\mathrm{CH}_{2} \mathrm{Cl}_{2}$ (59.6\%), conformer $\mathbf{2 d}$ becomes the global minimum in acetonitrile (56.3\%; Figure 8). Thus, conformer 2d, which forms the weakest IHB, is the most stable in polar solvents for both $\mathbf{1}$ and 2. Amide $\mathrm{I}$ bands in $\mathrm{H}_{2} \mathrm{O}$ (Figure 8e) and $\mathrm{D}_{2} \mathrm{O}$ (Figure 8f) are 
sharper for $\mathbf{2}$ than for $\mathbf{1}$ (cf. Figure 4e,f), but show some shoulders in the Amide II band. This could be taken as indication that there is more than one conformer in water, which could be both $\mathbf{2 b}$ and $\mathbf{2 d}$. a)

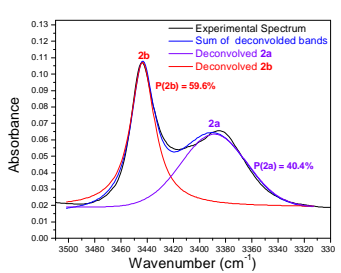

c)

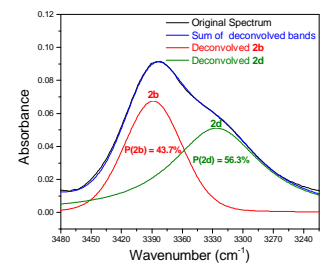

e)

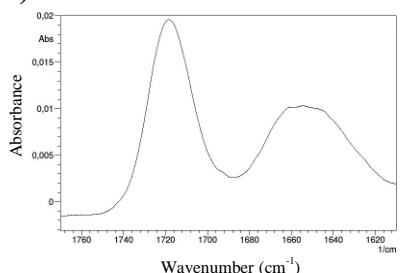

b)

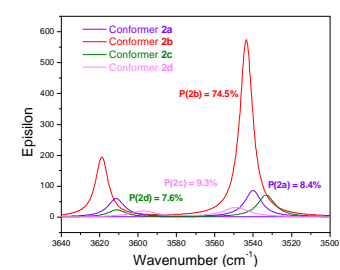

d)

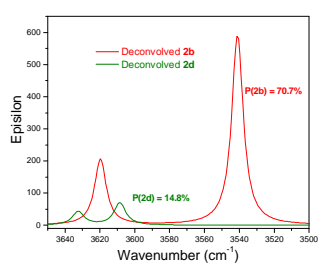

f)

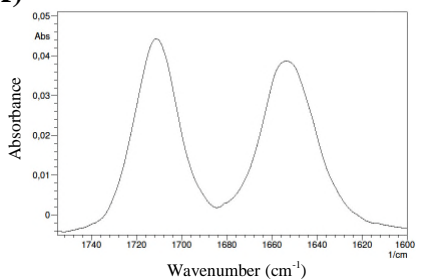

Figure 8: IR $\mathrm{N}-\mathrm{H}$ stretchings $(\mathrm{a}-\mathrm{d})$ and $\mathrm{C}=\mathrm{O}$ stretching regions (e,f) for 2. a) Experimental deconvoluted spectrum in $\mathrm{CH}_{2} \mathrm{Cl}_{2}$. b) Theoretical B3LYP-D3/aug-cc-pVDZ IR spectrum in $\mathrm{CH}_{2} \mathrm{Cl}_{2}$ (IEF-PCM). c) Experimental deconvoluted spectrum in $\mathrm{CH}_{3} \mathrm{CN}$. d) Theoretical B3LYP-D3/aug-cc-pVDZ IR spectrum in $\mathrm{CH}_{3} \mathrm{CN}$ (IEF-PCM). e) Experimental spectrum in $\mathrm{H}_{2} \mathrm{O}$. f) Experimental spectrum in $\mathrm{D}_{2} \mathrm{O}$. Conformer populations are indicated in each spectrum. Experimental IR populations were corrected by conformer calculated molar absortivities.

Table 6: Experimental chemical shifts (ppm) and ${ }^{3} J_{\mathrm{HH}}$ spin-spin coupling constants (SSCCs, Hz) of $\mathrm{CF}_{3}-\mathrm{C}(\mathrm{O})$-Gly-NHMe in solvents with different dielectric constants $(\varepsilon)$.<smiles>CN(C)C(=O)CNC(=O)C(F)(F)F</smiles>

\begin{tabular}{cccccccc}
\hline Solvent & $\boldsymbol{\varepsilon}$ & $\boldsymbol{\delta \mathbf { H } _ { ( \mathbf { a } ) }}$ & $\boldsymbol{\delta \mathbf { H } _ { ( \mathbf { b } ) }}$ & $\boldsymbol{\delta \mathbf { H } _ { ( \mathrm { c } ) }}$ & $\boldsymbol{\delta \mathbf { H } _ { ( \mathbf { d } ) }}$ & ${ }^{\mathbf{3}} \boldsymbol{J}_{\mathbf{H a H b}}$ & ${ }^{3} \boldsymbol{J}_{\mathbf{H c H d}}$ \\
\hline $\mathbf{C D}_{\mathbf{2}} \mathbf{C l}_{\mathbf{2}}$ & 8.9 & 7.19 & 3.96 & 5.62 & 2.84 & 4.68 & 4.86 \\
Acetone-d $_{\mathbf{6}}$ & 20.7 & 8.53 & 3.97 & 7.31 & 2.73 & 5.64 & 4.74 \\
Acetonitrile-d $_{\mathbf{3}}$ & 37.5 & 7.76 & 3.84 & 6.50 & 2.69 & 4.98 & 4.75 \\
DMSO-d $_{\mathbf{6}}$ & 46.7 & 9.62 & 3.76 & 7.98 & 2.60 & 5.88 & 4.62 \\
$\mathbf{C D}_{\mathbf{3}} \mathbf{O H}$ & 32.7 & --- & 3.91 & 8.03 & 2.75 & --- & 4.63 \\
$\mathbf{H}_{2} \mathbf{O}$ & 80.1 & --- & 4.02 & 7.99 & 2.75 & --- & --- \\
\hline
\end{tabular}

${ }^{1} \mathrm{H}$ NMR parameters for $\mathbf{2}$ are collected in Table 6. Unfortunately, the $\mathrm{H}(\mathrm{N})$ atom in $\mathbf{2}$ is much more acidic than in 1 and exchanges quite fast within polar protic solvents. It is thus not possible to determine ${ }^{3} J_{\mathrm{HaHb}}$ SSCC in methanol and water, which could have indicated if either $\mathbf{2 b}$ or $\mathbf{2 d}$ would be the preferential one, since they have different calculated ${ }^{3} J_{\mathrm{HaHB}}$ values (ESI Table S5).
Another way to probe if either the $\mathbf{b}$ or $\mathbf{d}$ conformer would be the preferential one in polar protic solvents, is to look at derivatives where one of them is disfavoured by design. Conformers $\mathbf{1 d}$ and $\mathbf{2 d}$ are stabilised by an IHB involving the C-terminal NHMe group (Figure 2). Because changing this group to $\mathrm{NMe}_{2}$ should block this interaction, we finally studied Ac-Gly-N(Me) $)_{2}$ (3). Theoretical calculations indicate that $\mathbf{3 b}$ has $\sim 90 \%$ of the total population in all solvents (Table 5) and that, as expected, the geometries of conformers $\mathbf{a}$ and $\mathbf{d}$ are not the same as for compounds $\mathbf{1}$ and $\mathbf{2}$ (Figure 2). This has consequences for the chemical shifts and SSCCs (Table 7). Thus, if $\mathbf{3 b}$ is the preferential conformer, with $\sim 90 \%$ of the total population in all solvents, one would expect that the experimental ${ }^{3} J_{\mathrm{HaHb}}$ SSCC would decrease considerably for $\mathbf{3}$ in comparison to $\mathbf{1}$ and $\mathbf{2}$. However, as shown in Table 7, the ${ }^{3} J_{\mathrm{HaHb}}$ SSCCs for $\mathbf{3}$ are overall only slightly smaller than those observed in 1.

Table 7: Experimental Chemical shift values (ppm) and ${ }^{3} J_{\mathrm{HH}}$ spinspin coupling constant (SSCC) values $(\mathrm{Hz})$ of $\mathrm{Ac}-\mathrm{Gly}-\mathrm{N}(\mathrm{Me})_{2}$ in solvents with different dielectric constants $(\varepsilon)$.<smiles>CC(=O)NCC(=O)N(C)C</smiles>

\begin{tabular}{|c|c|c|c|c|c|c|c|}
\hline Solvent & $\varepsilon$ & $\delta \mathbf{H}_{(\mathrm{a})}$ & $\delta \mathbf{H}_{(\mathbf{b})}$ & $\delta \mathbf{H}_{(\mathrm{c})}$ & $\delta \mathbf{H}_{(\mathrm{d})(\mathrm{e})}{ }^{[\mathrm{a}]}$ & $\delta \mathrm{H}(\mathrm{d})(\mathrm{e})^{[\mathrm{a}]}$ & ${ }^{3} J_{\mathrm{HaHb}}$ \\
\hline $\mathrm{CD}_{2} \mathrm{Cl}_{2}$ & 8.9 & 6.81 & 4.00 & 1.99 & 2.96 & 2.94 & 4.26 \\
\hline Acetone- $d_{6}$ & 20.7 & 7.19 & 3.98 & 1.93 & 2.90 & 3.01 & 4.80 \\
\hline Acetonitrile-d $\mathbf{d}_{3}$ & 37.5 & 6.75 & 3.93 & 1.92 & 2.88 & 2.93 & 5.16 \\
\hline DMSO-d $_{6}$ & 46.7 & 7.91 & 3.89 & 1.86 & 2.94 & 2.82 & 5.46 \\
\hline $\mathrm{CD}_{3} \mathrm{OH}$ & 32.7 & 8.07 & 4.05 & 2.02 & 3.05 & 2.96 & 5.04 \\
\hline $\mathrm{H}_{2} \mathrm{O}$ & 80.1 & --- & 4.07 & 2.05 & 3.03 & 2.93 & --- \\
\hline
\end{tabular}

${ }^{[\mathrm{a}]} \mathrm{H}_{(\mathrm{d})}$ and $\mathrm{H}_{(\mathrm{e})}$ were not assigned.

Experimental IR spectra of compound 3 in $\mathrm{CD}_{2} \mathrm{Cl}_{2}$, acetonitrile and water are shown in Figure 9. In excellent agreement with theoretical calculations, experimental IR populations indicate that conformer3b is the most prevalent in $\mathrm{CH}_{2} \mathrm{Cl}_{2}$ accounting for $93.4 \%$ of the total population (Figure 9). The $\mathrm{N}-\mathrm{H}$ band is very broad in acetonitrile and conformer populations could not be taken from it..Conformers $\mathbf{3 c}$ and $\mathbf{3 d}$ have the highest calculated dipole moment values (10.31 D and $10.08 \mathrm{D}$, respectively), while $\mathbf{3 b}$ has a relative small calculated dipole moment $(4.62$ D). Differently from compounds $\mathbf{1}$ and $\mathbf{2}$, the amide I IR band of compound $\mathbf{3}$ has a shoulder in water (Figure 3f), hence, indicating that more than one conformer is stable in this solvent. Thus, even though $\mathbf{3 b}$ has an extended geometry and is more prone to be solvated by water, such conformer would not be the most stable in more polar or polar protic solvents if other conformers with higher dipole moments are present. This may also be the case for compounds $\mathbf{1}$ and $\mathbf{2}$, whose conformers $\mathbf{1 b}$ and $\mathbf{2 b}$ compete with $\mathbf{1 d}$ and $\mathbf{2 d}$, respectively, in polar solvents. However, as shown previously, d conformers have higher dipole moments than b conformers and, consequently, should be the preferential ones in polar and polar protic solvents. 
a)

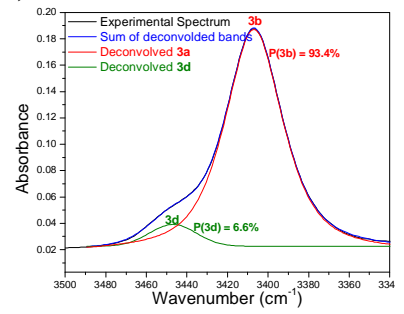

c)

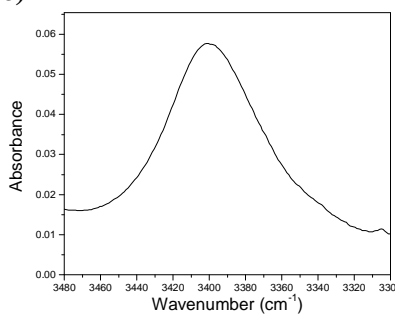

e)

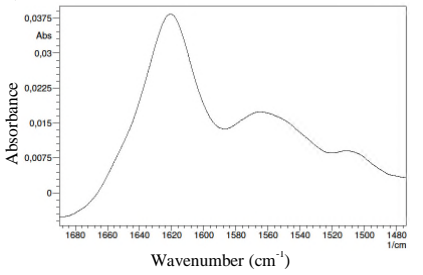

b)

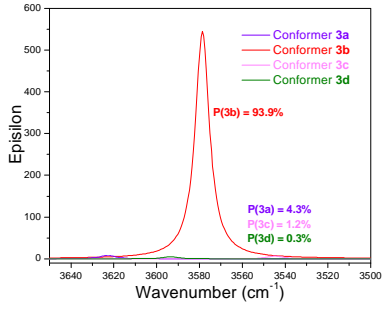

d)

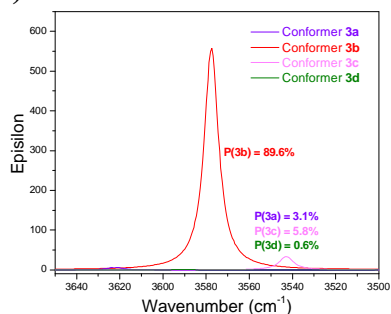

f)

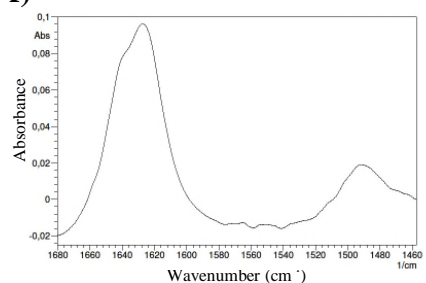

Figure 9: $\mathrm{IR} \mathrm{N}-\mathrm{H}$ stretching $(\mathrm{a}-\mathrm{d})$ and $\mathrm{C}=\mathrm{O}$ stretching regions $(\mathrm{e}, \mathrm{f})$ regions for 3. a) Experimental deconvoluted spectrum in $\mathrm{CH}_{2} \mathrm{Cl}_{2}$. b) Theoretical B3LYP-D3/aug-cc-pVDZ IR spectrum in $\mathrm{CH}_{2} \mathrm{Cl}_{2}$ (IEF-PCM). c) Experimental deconvoluted spectrum in $\mathrm{CH}_{3} \mathrm{CN}$. d) Theoretical B3LYP-D3/aug-cc-pVDZ IR spectrum in $\mathrm{CH}_{3} \mathrm{CN}$ (IEF-PCM). e) Experimental spectrum in $\mathrm{H}_{2} \mathrm{O}$. f) Experimental spectrum in $\mathrm{D}_{2} \mathrm{O}$. Conformer populations are indicated in each spectrum. Experimental IR populations were corrected by conformer calculated molar absortivities.

\section{Conclusions}

The conformational preferences of Ac-Gly-NHMe change considerably from nonpolar solvents such as $\mathrm{CH}_{2} \mathrm{Cl}_{2}$ to polar $\left(\mathrm{CH}_{3} \mathrm{CN}\right)$ and polar protic solvents (methanol and water). Theoretical calculations and experimental IR indicate that the conformational preferences of Ac-Gly-NHMe shifts from 1a, which is stabilised by a strong $\mathrm{N}-\mathrm{H} \cdots \mathrm{O}$ IHB and is prevalent for the isolated molecule and in nonpolar solvents, to conformers 1b and 1d, which are stabilised to a lesser extent by IHBs and have higher dipole moments (for 1d). These results are supported by experimental ${ }^{3} J_{\mathrm{HaHb}}$ SSCC values and theoretical calculations. The IR and ${ }^{1} \mathrm{H}$ NMR experimental and theoretical results obtained for $\mathrm{CF}_{3}-\mathrm{C}(\mathrm{O})-\mathrm{Gly}-\mathrm{NHMe}$ and Ac-Gly-N(Me) derivatives highlight the results obtained for Ac-Gly-NHMe, indicating that conformers with higher dipole moments such as 1d in Ac-Gly-NHMe may be the preferential ones in polar protic solvents. We hope that the results of this work may help to understand the conformational behaviour of glycine residues in peptides, proteins and smaller models thereof in either nonpolar and polar environments.

The authors thank a Grant \# 2012/03933-5, São Paulo Research Foundation (FAPESP) for providing financial support for this research and a scholarship to RAC \#2011/01170-1 (FAPESP). CNPq is also acknowledged, such as for fellowships (to RR) and a studentship (to RAC). MB thanks the School of Chemistry and EaStCHEM for support and for access to a computer cluster maintained by Dr. H. Früchtl.

\section{Notes and references}

${ }^{a}$ EastChem School of Chemistry, University of St Andrews, North Haugh, St Andrews, Fife, KY16 9ST, UK.

E-mail:mb105@st-andrews.ac.uk and rittner@iqm.unicamp.br.

${ }^{b}$ Chemistry Institute, State University of Campinas, P.O. Box 6154, 13083-970, Campinas, SP, Brazil.

Electronic Supplementary Information (ESI) available: 1-3 compounds PES, conformer geometrical representations. QTAIM, ELF, NCI and DORI details and experimental and theoretical IR and NMR spectra. See DOI: 10.1039/b000000x/

1 (a) C. K. Kim, B.-H. Park, H. W. Lee, C. K. Kim, Org. Biomol. Chem., 2013, 11, 1407. (b) J. Groule, F. Jensen, J. Chem. Theory Comput., 2011, 7, 1783. (c) L. Comez, L. Lupi, A. Morresi, M. Paolantoni, P. Sassi, D. Fioretto, J. Phys. Chem. Lett., 2013, 4, 1188. (d) D. Russo, M. A. Gonzalez, E. Pellegrini, J. Combet, J. Ollivier, J. Teixeira, J. Phys. Chem. B, 2013, 117, 2829. (e) V. L. Cruz, J. Ramos, J. Martinez-Salazar, J. Phys. Chem. B, 2012, 116, 469. (f) B. M. Marsh E. M. Duffy, M. T. Soukup, J. Zhou, E. Garand, J. Phys. Chem. A, 2014, 118, 3906. (g) E. V. Dornshuld, R. A. Vergenz, G. S. Tschumper, J. Phys. Chem. B 2014, 118, 8583. h) R. Schweitzer-Stenner, Biophys. J., 2002, 83, 523. i) H. Torii J. Phys. Chem. A, 2006, 110, 4822. i) M. Candelaresi, E. Ragnoni, C. Cappelli, A. Corozzi, M. Lima, S. Monti, B. Mennucci, F. Nuti, A. M. Papini, P. Foggi J. Phys. Chem. B, 2013, 117, 14226.

2 (a) B. J. Tooze Introduction to Protein Structure, Garland, New York, 1991.(b) H. Dong, M. Sharma, H.-X. Zhou, T. A. Cross Biochem., 2012, 51, 4779 (c) D. Russo, J. Teixeira, L. Kneller, J. R. D. Copley, J. Ollivier, S. Perticaroli, E. Pellegrini, M. A. Gonzalez, J. Am. Chem. Soc., 2011, 133, 4882. d) M. C. Asplund, M. T. Zanni, R. M. Hochstrasser Proc. Natl. Acad. Sci. U.S.A., 2000, 97, 8219.

3 (a) V. Barone, M. Biczysko, J. Bloino, C. Puzzarini, Phys. Chem. Chem. Phys., 2013, 15, 10094. (b) B. M. Marsh, E. M. Duffy, M. T. Soukup, J. Zhou, E. Garand, J. Phys. Chem. A 2014, 118, 3906. (c) V. Barone, M. Biczysko, J. Bloino, C. Puzzarini, J. Chem. Theory Comput., 2013, 9, 1533. (d) V. Barone, M. Biczysko, J. Bloino, C. Puzzarini Phys. Chem. Chem. Phys., 2013, 15, 1358.

4 (a) J. L. Alonso, I. Peña, J. C. López, V. Vaquero, Angew. Chem., 2009, 121, 6257. (b) R. M. Balabin, Phys. Chem. Chem. Phys., 2010, 12, 5980. (c) J. Oomens, J. D. Steill, B. Redlich, J. Am. Chem. Soc., 2009, 131, 4310.

5 (a) V. Pophristic, L. Goodman, Nature, 2001, 411, 565-568. (b) R. A. Cormanich, M. P. Freitas J. Org. Chem., 2009, 74, 8384-8387. (c) Y. Mo J. Org. Chem., 2010, 75, 2733-2736.

6 (a) R. A. Cormanich, L. C. Ducati, R. Rittner, Chem. Phys., 2011, 387, 85. (b) R. A. Cormanich, L. C. Ducati, R. Rittner, J. Mol. Struct., 2012, 1014, 12. (c) R. A. Cormanich, L. C. Ducati, C. F. Tormena, R. Rittner, Chem. Phys., 2013, 421, 32. (d) R. A. Cormanich, L. C. Ducati, C. F. Tormena, R. Rittner, J. Phys. Org. Chem., 2013, 26, 849. (e) C. J. Duarte, R. A. Cormanich, L. C. Ducati, C. F. Tormena, R. Rittner, J. Mol. Struc., 2013, 1050, 174. (f) R. A. Cormanich, L. C. Ducati, C. F. Tormena, R. Rittner, Spectrochim. Acta, 2014, 123, 482

\section{Acknowledgements}


7 R. F. W. Bader, Atoms in Molecules: A Quantum Theory, Clarendon, Oxford, 1990.

8 B. Silvi, A. Savin, Nature, 1994, 371, 683.

9 E. Johnson, S. Keinan, P. Mori-Sánchez, J. Contreras-García, A. Cohen, W. Yang, J. Am. Chem. Soc., 2010, 132, 6498.

10 P. de Silva, C. Corminboeuf, J. Chem. Theory Comput., 2014, 10, 3745.

11 A. E. Reed, L. A. Curtiss, F. Weinhold, Chem. Rev., 1988, 88, 889.

12 (a) M. Piotto, V. Saudek and V. Slenár, J. Biomol. NMR, 1992, 2, 661.(b) V. Sklenár, M. Piotto, R. Leppik and V. Saudek, J. Magn. Reson. A, 1993, 102, 241.

13 D.I. Hoult, J. Magn. Reson., 1976, 21, 337.

14 Grams/AI v. 9.0, ThermoFisher, Woburn, MA, USA (2009).

15 Gaussian 09, Revision D.01, M. J. Frisch, G. W. Trucks, H. B. Schlegel, G. E. Scuseria, M. A. Robb, J. R. Cheeseman, G. Scalmani, V. Barone, B. Mennucci, G. A. Petersson, H. Nakatsuji, M. Caricato, X. Li, H. P. Hratchian, A. F. Izmaylov, J. Bloino, G. Zheng, J. L. Sonnenberg, M. Hada, M. Ehara, K. Toyota, R. Fukuda, J. Hasegawa, M. Ishida, T. Nakajima, Y. Honda, O. Kitao, H. Nakai, T. Vreven, J. A. Montgomery, Jr., J. E. Peralta, F. Ogliaro, M. Bearpark, J. J. Heyd, E. Brothers, K. N. Kudin, V. N. Staroverov, R. Kobayashi, J. Normand, K. Raghavachari, A. Rendell, J. C. Burant, S. S. Iyengar, J. Tomasi, M. Cossi, N. Rega, J. M. Millam, M. Klene, J. E. Knox, J. B. Cross, V. Bakken, C. Adamo, J. Jaramillo, R. Gomperts, R. E. Stratmann, O. Yazyev, A. J. Austin, R. Cammi, C. Pomelli, J. W. Ochterski, R. L. Martin, K. Morokuma, V. G. Zakrzewski, G. A. Voth, P. Salvador, J. J. Dannenberg, S. Dapprich, A. D. Daniels, Ö. Farkas, J. B. Foresman, J. V. Ortiz, J. Cioslowski, and D. J. Fox, Gaussian, Inc., Wallingford CT, 2009.

16 Because the larger quantity of conformers studied in the present work, it was not used the commonly adopted nomenclature from the literature: A. Perczel, J. G. Angyin, M. Kajtar, W. Viviani, J.-L. Rivail, J. F. Marcoccia, I. G. Csizmadia, J. Am. Chem. Soc. 1991, 113, 6256.

17 Y. Shao, L.F. Molnar, Y. Jung, J. Kussmann, C. Ochsenfeld, S.T. Brown, A.T.B. Gilbert, L.V. Slipchenko, S.V. Levchenko, D.P. O'Neill, R.A. DiStasio Jr., R.C. Lochan, T. Wang, G.J.O. Beran, N.A. Besley, J.M. Herbert, C.Y. Lin, T. Van Voorhis, S.H. Chien, A. Sodt, R.P. Steele, V.A. Rassolov, P.E. Maslen, P.P. Korambath, R.D. Adamson, B. Austin, J. Baker, E.F.C. Byrd, H. Dachsel, R.J. Doerksen, A. Dreuw, B.D. Dunietz, A.D. Dutoi, T.R. Furlani, S.R. Gwaltney, A. Heyden, S. Hirata, C-P. Hsu, G. Kedziora, R.Z. Khalliulin, P. Klunzinger, A.M. Lee, M.S. Lee, W.Z. Liang, I. Lotan, N. Nair, B. Peters, E.I. Proynov, P.A. Pieniazek, Y.M. Rhee, J. Ritchie, E. Rosta, C.D. Sherrill, A.C. Simmonett, J.E. Subotnik, H.L. Woodcock III, W. Zhang, A.T. Bell, A.K. Chakraborty, D.M. Chipman, F.J. Keil, A.Warshel, W.J. Hehre, H.F. Schaefer, J. Kong, A.I. Krylov, P.M.W. Gill and M. Head-Gordon, Phys. Chem. Chem. Phys., 2006, 8, 3172.

18 S. Grimme, S. Ehrlich, L. Goerigk, J. Comput. Chem., 2011, 32, 1456.

19 S. Grimme, J. Antony, S. Ehrlich, H. Krieg, J. Chem. Phys. 2010, 132, 154104

20 (a) H.-J. Werner, P. J. Knowles, G. Knizia, F. R. Manby and M. Schütz, WIREs Comput. Mol. Sci., 2012, 2, 242 (b) MOLPRO, version 2012.1, a package of ab initio programs, H.-J. Werner, P. J. Knowles, G. Knizia, F. R. Manby, M. Schütz, P. Celani, T. Korona, R. Lindh, A. Mitrushenkov, G. Rauhut, K. R. Shamasundar, T. B. Adler, R. D. Amos, A. Bernhardsson, A. Berning, D. L. Cooper, M. J. O. Deegan, A. J. Dobbyn, F. Eckert, E. Goll, C. Hampel, A. Hesselmann, G. Hetzer, T. Hrenar, G. Jansen, C. Köppl, Y. Liu, A. W. Lloyd, R. A. Mata, A. J. May, S. J. McNicholas, W. Meyer, M. E.
Mura, A. Nicklass, D. P. O'Neill, P. Palmieri, D. Peng, K. Pflüger, R. Pitzer, M. Reiher, T. Shiozaki, H. Stoll, A. J. Stone, R. Tarroni, T. Thorsteinsson, and M. Wang, , see http://www.molpro.net.

21 Scalmani G., Frisch M. J., J. Chem. Phys., 2010, 132, 114110.

22 A. D. Becke, J. Chem. Phys., 1993, 98, 5648.

23 V. Barone, in Recent Advances in Density Functional Methods, Part I, Ed. Chong, D. P., World Scientific Publ. Co., Singapore, 1996.

24 F. Nozirov, T. Kupka, M. Stachów, J. Chem. Phys. 2014, 140, 144303.

25 Suardíaz, R.; Pérez, C.; Crespo-Otero, R.; García de la Vega, J. M.; San Fabián, J., J. Chem. Theor. Comput., 2008, 4, 448.

26 T. Enevoldsen, J. Oddershede, S. P. A. Sauer, Theor. Chem. Acc.,1998, 100, 275.

27 Dalton, a Molecular Electronic Structure Program, Release DALTON2013.0 (2013), see http://daltonprogram.org/

28 AIMAll (Version 14.06.21), T. A. Keith, TK Gristmill Software, Overland Park KS, USA, 2013 (aim.tkgristmill.com).

29 S. Noury, X. Krokidis, F. Fuster, B. Silvi, ToPMoD, Laboratoire de Chemie Théorique, Université Pierre et Marie Curie.: París, http://www.lct.jussieu.fr/pagesperso/silvi/topmod english.html 1999.

30 K.-C. Chou, Anal. Biochem., 2000, 286, 1.

31 Y. K. Kang, J. B. Byun, J. Comput. Chem., 2010, 31, 2915.

32 We note that "C5" isomers akin to $\mathbf{1 b}$ can have N-H streching frequencies below $3400 \mathrm{~cm}^{-1}$ (e.g. for $\mathrm{C}^{\alpha}$-tetrasubstituted homopeptides: M. Crisma, A. Moretto, C. Peggion, L. Panella, B. Kaptein, Q. B. Broxterman, F. Formaggio and C. Toniolo, Amino Acids, 2011, 41, 629); our assignment of frequencies above that value is in accordance with the computations.

33 (a) J. R. Lane, J. Contreras-Garcia, J.-P. Piquemal, B. J. Miller, and H. G. Kjaergaard, J. Chem. Theory Comp., 2013, 9, 3263. (b) F. Weinhold, P. R. Schleyer, W. C. McKee., J. Comp. Chem., 2014, 35, 1499.

34 F. Fuster, B. Silvi, Theor Chem Acc., 2000, 104, 13.

35 E. D. Glendening, F. Weinhold, J. Comp. Chem., 1998, 19, 593.

36 (a) A. Otero-de-la-Roza, E. R. Johnson, J. Contreras-García, Phys. Chem. Chem. Phys., 2012, 14, 12165. (b) R. A. Cormanich, R. Rittner, M. P. Freitas, M. Bühl. Phys. Chem. Chem. Phys. 2014, 16, 19212. (c) R. A. Cormanich, R. Rittner, D. O'Hagan, M. Bühl, J. Phys. Chem. A, 2014, 118, 7901.

37 P. R. Rablen, R. W. Hoffmann, D. A. Hrovat, W. T. J. Bordenc, Chem. Soc. Perk. Trans. 2, 1999, 2, 1719.

38 J. K. Badenhoop, F. Weinhold, J. Chem. Phys. 1997, 107, 5406.

39 M. Karplus, J. Chem. Phys. 1959, 30, 11.

40 H. Hu, M. Elstner, J. Hermans, Proteins: Struct., Funct., Genet., 2003, 50, 451.

41 S. Boopathi, Kolandaivel, P. J. Biomol. Struct. Dyn. 2013, 30, 158. 